\title{
"FALAR SOBRE GÊNERO É FALAR LÁ NO OITO DE MARÇO" - trajetórias de mulheres sindicalistas e seus posicionamentos sobre a importância do gênero no sindicato e na escola ${ }^{1}$
}

\author{
Márcia Ondina Vieira Ferreira \\ Universidade Federal de Pelotas - UFPel
}

\begin{abstract}
Resumo
O texto desenvolve recorte de pesquisa voltada a compreender o que convoca professoras à participação na vida sindical. Aqui serão resgatados dois aspectos evidenciados no estudo: (1) particularidades das trajetórias familiares, educacionais, profissionais e políticas de mulheres sindicalistas atuantes no CPERS/SINDICATO; (2) representações dessas mulheres sobre a importância da categoria gênero no sindicato e na escola. Em termos metodológicos, trata-se de pesquisa qualitativa baseada em entrevistas semiestruturadas. Dentre os resultados pode-se dizer que as vivências das entrevistadas se manifestaram ricas em experiências; semelhantes em vários aspectos; adquirindo a militância importância ímpar; e que são certamente caracterizadas pelo gênero, embora nem todas tenham consciência disso. É perceptível, no entanto, ser a diferença geracional um dos traços marcantes a definir posicionamentos diversos sobre vários aspectos da vida das professoras, tanto no que se refere às concepções sobre gênero e seu debate no sindicato e na escola, quanto à vivência sindical e profissional.
\end{abstract}

Palavras-chave: gênero; mulheres; sindicalismo de trabalhadoras/es em educação; trabalho docente.

\begin{abstract}
The text comprises a cutting of a research aimed at understanding at what makes female teachers join the union life. Here we focus on two aspects highlighted in the study: (1) particularities in the family, educational, professional and political stories of unionist women working at CPERS/SINDICATO; (2) representations of these women on the importance of gender both at the union and at school. In methodological terms, it consists of a qualitative research based on semistructured interviews. Among the results obtained it is possible to say that the experiences of the interviewees were manifested in rich experiences; similar in several aspects; acquiring unique importance for the militancy; and that are surely characterized by gender, although not all are aware of that. It is noticeable, though, that the generational differences are a remarkable detail to define different opinions concerning aspects of life of the teachers, both concerning their conceptions about gender and their debate at the union and at school, in terms of their union and professional experience.
\end{abstract}

Keywords: gender; women; unionism of people working in education; teaching work. 


\section{Caracterização do estudo}

Em estudos prévios já discorri sobre trajetórias de ativistas de sindicatos em educação, tendo o gênero como eixo de análise (Ferreira; 2006a; 2012). Dirigi-me a esses estudos pela necessidade de conhecer como as pessoas se tornaram docentes, tendo em vista sua origem familiar/social, as alternativas educacionais à sua disposição e considerando a ênfase que a família dava à escolarização como estratégia de reprodução social (Bourdieu, 1999b). Pensava - e penso ainda - que estudar a trajetória desses e dessas docentes poderia contribuir para compreender a constituição do corpo profissional docente brasileiro entre pessoas com faixa etária semelhante.

Escolher sindicalistas foi fruto da hipótese de que conformariam um grupo de informantes-chave (Iñiguez, 2004), pessoas que, por sua familiaridade com o objeto de análise da pesquisadora - o exercício da docência em condições concretas - teriam informações sui generis a respeito. Agrega-se a isso o fato de que a sindicalização de docentes posteriormente à Constituição de 1988 revelava uma das expressões identitárias do professorado, paulatinamente reunido em sindicatos de "trabalhadores em educação" (Ferreira, 2006b; 2007).

Com o tempo percebi a validade de usar as relações de gênero para mediar essa análise. De fato, quando o gênero dá forma a essas reflexões, pode-se tentar vislumbrar diferenças nos trajetos de vida de homens e de mulheres, que ganham maior sentido quando se tenta entender, igualmente, como algumas delas e vários deles - em comparação com a base da categoria, composta por 79,7\% de mulheres no ensino básico, em números de 2019 (INEP, 2020) - tornaram-se militantes sindicais.

Sobre isso é preciso destacar a existência de toda uma literatura que se ocupa dos lugares sociais atribuídos às pessoas conforme o gênero, adquirindo maior importância para este estudo a parcela voltada à divisão sexual do trabalho. Por exemplo, as estudiosas das relações sociais de sexo assinalam que, embora cada sociedade tenha uma forma particular de exercício da divisão sexual do trabalho, existem alguns princípios presentes em todas as sociedades: o encaminhamento prioritário dos homens para funções produtivas e da mulheres para funções reprodutivas; a separação por tipos de trabalho (femininos/masculinos); a maior valorização do tipo de trabalho masculino; a ocupação masculina de funções sociais com máximo reconhecimento (funções políticas, militares, religiosas, científicas, de gestão empresarial) etc. (Kergoat, 2009).

De forma semelhante, existe um gênero de estudos que tem por objeto examinar como ocorre o desenvolvimento da carreira de homens e de mulheres, e de homens em profissões tipicamente femininas, usando ou não os epítetos de "teto de vidro (ou cristal)" (glass ceiling) e "escada rolante de cristal (ou vidro)" (glass escalator) para significar a existência de barreiras invisíveis ao êxito das mulheres, enquanto os homens parecem ter seu ascenso facilitado na carreira (Williams, 1992). Tais estudos têm sido relevantes para a tentativa de compreender-se carreiras da gestão empresarial (Carrieri; Teixeira; Nascimento, 2016); enquanto outras estudiosas ocupam-se de diferentes carreiras no campo da ciência (Schiebinger, 2001). No campo específico da educação vale lembrar um assunto várias vezes 
mencionado, mas não suficientemente aprofundado na literatura sobre trabalho docente. $\mathrm{O}$ discurso escolar tende a legitimar os padrões tradicionais de masculinidade e de feminilidade (Alonso; Morgade, 2008), o que explica a tendência, entre outras coisas, a ampliar a presença de homens quanto mais aumenta a idade do alunado; a estranhar e, até mesmo, tentar evitar sua presença nas séries iniciais da escolarização; ou a colocá-los na gestão escolar e dos diferentes sistemas escolares, enquanto as mulheres ocupam-se, prioritariamente, das tarefas de caráter pedagógico.

Por fim, para citar outro tipo de investigação, Born (2001), em sua análise sobre trajetórias, e baseando-se no conceito de biografia normal, cunhado por René Levy, destaca que há ao menos dois tipos de biografias normais num mesmo país, ou seja, considerando-se variáveis culturais comuns e aportes institucionais estruturadores das biografias: as biografias de mulheres e as de homens.

Significa, portanto, que há diferença de gênero. Uma típica trajetória de vida, ou aquela normal, de uma mulher, apresenta-se diferente da do homem e, da mesma forma, as mulheres têm percepções de trajetórias de vida diferentes das que os homens têm a respeito de suas próprias vidas (Born, 2001, p. 243).

Neste sentido, tornou-se importante para mim aprofundar a questão da presença feminina e masculina nos sindicatos de trabalhadoras/es em educação, sob a hipótese de que, tomando por referência a ideia de diferenças nos caminhos percorridos por homens e mulheres nos diversos espaços de poder social, político e econômico, seria perceptível algo semelhante entre sindicalistas. Isso foi desenvolvido numa série de pesquisas empíricas, que fizeram uso das poucas referências existentes na bibliografia nacional sobre sindicatos em educação e gênero, mormente aproveitando os estados da arte de Vianna (2001) e Coronel (2014); de bibliografia que aborda a presença de mulheres no espaço sindical em geral (por exemplo: Cappellin, 1994; Delgado, 1998; Rodríguez, 2006); e de bibliografia que analisa a participação de mulheres em instâncias de poder político (tais como Fraser, 1995; Miguel; Biroli, 2013).

Nas pesquisas citadas outro elemento que se tornou elucidativo em termos de diferenças por gênero é a forma de construção do discurso, pois a oportunidade de narrar sua própria vida parece ser influenciada pelo estágio de participação na esfera pública, ou seja, é maior para os homens e menor para as mulheres. Em sendo assim, é mais fácil aos homens julgarem-se competentes para encarregar-se de tarefas ou ocupar posições de comando (Bourdieu, 1999a) e, enquanto o discurso desses apresenta-se de forma mais linear - como se conseguissem vislumbrar sua trajetória como uma história já escrita e documentada -, o discurso das mulheres é mais entrecortado, menos teleológico, mais tateante.

Por outra parte, uma segunda temática abordada em minhas pesquisas refere-se às representações de gênero de sindicalistas. Considerando-se o fato de que a docência foi construída como um trabalho de mulher (Almeida, 1998; Louro, 1998), qual a reflexão que as sindicalistas apresentam sobre isso? Qual o grau de intervenção que acreditam deva ter o sindicato nessas discussões? Como veem - ou não - a presença das diferenças de gênero na 
escola? Observe-se que, no Brasil, se a reflexão propriamente acadêmica sobre gênero, docência e escola se intensifica a partir dos anos 1980 - veja-se, entre outras possibilidades, Rosemberg (1985); Louro (1987); Bruschini; Amado (1988) -, nas organizações sindicais da educação ela aparece mais tardiamente, principalmente a partir do final dos anos 1990, acompanhando em especial o desenvolvimento das políticas públicas para gênero pleiteadas pelos movimentos de mulheres e LGBT+ (Ferreira; Santos; Coronel; Orsato, 2017; Santos, 2020).

Igualmente podemos comprovar a boa quantidade de estudos em geral sobre gênero e educação, abordando as práticas pedagógicas, a avaliação educacional, a elaboração de materiais didáticos, as interações cotidianas etc., que passaram a iluminar, em maior ou menor medida, as políticas de transformação de currículos do ensino básico e os processos de formação do professorado brasileiro. Para ter-se apenas uma ideia muito pequena desses estudos no âmbito nacional, pode-se consultar os trabalhos de Auad (2006); Carvalho (1999; 2001); Louro (1998); Paraíso (2016); ou, mesmo, um estado da arte como o de Vianna et alii (2011).

Contudo, aqui é preciso apresentar uma inflexão que justifica os questionamentos deste artigo. Apesar do grande crescimento, sucedido nas últimas décadas, da elaboração teórica e da discussão sobre gênero e diversidade sexual no ambiente acadêmico e no escolar, mais recentemente houve grandes retrocessos nas políticas para gênero no país. Esses retrocessos incluem o uso do slogan "ideologia de gênero", cunhado pela Igreja Católica, por parte de bancadas como a Frente Parlamentar Evangélica, entre outros agrupamentos, visando retirar o termo gênero do Plano Nacional de Educação, sob a alegação de que as diferenças entre os sexos seriam resultado da natureza (ou de desígnio divino), não cabendo a discussão sobre desigualdades daí advindas. Tais disputas iniciaram por volta de 2010 e se estendem de tal forma que influenciaram planos estaduais e municipais de educação (Silva, 2018) ${ }^{2}$. Desde aí acirraram-se as investidas pela retirada das discussões nos meios escolares e nas políticas educacionais e a culpabilização de docentes por uma suposta defesa da "ideologia de gênero". Tais investidas têm sido capitaneadas, entre outros, pelos defensores do movimento Escola Sem Partido (https://www.escolasempartido.org/), desencadeando uma verdadeira "caça às bruxas" entre o professorado (Ramos, 2017). Num cenário desse tipo ${ }^{3}$, como, então, as sindicalistas se pronunciariam sobre a relevância da categoria gênero? Suas trajetórias teriam alguma importância para seu pronunciamento?

Tendo em vista esse conjunto de questões, neste artigo serão problematizados dois dos objetivos presentes na pesquisa original (Ferreira, 2018), quais sejam:

1) examinar as especificidades das trajetórias familiares, educacionais, profissionais e políticas de mulheres sindicalistas atuantes no Centro de Professores do Estado do Rio Grande do Sul - Sindicato dos Trabalhadores em Educação (CPERS/SINDICATO);

2) conhecer as representações dessas mulheres sobre a importância do gênero no sindicato e na escola.

Em termos metodológicos, trata-se de um estudo qualitativo, tendo por pressuposto que o resgaste das informações deve privilegiar o significado dado pelos sujeitos da pesquisa ao objeto analisado (Brandão, 2003). Neste sentido, no trecho aqui apresentado a técnica de 
construção de dados foi a entrevista semiestruturada, realizada com nove mulheres, de forma a captar suas representações a respeito das relações de gênero e instigá-las a reconstruir suas trajetórias.

Acompanho as reflexões de Hall (1997) para definir representação: descrição, por intermédio da linguagem, que alguém faz de alguma coisa, considerando-se que cada pessoa está imersa num mundo de significação. Já a noção de trajetórias resulta das leituras de Bourdieu, para quem a compreensão das biografias dos indivíduos exige situá-las nos contextos onde foram geradas e a partir da vivência com outros sujeitos em diferentes espaços sociais (Bourdieu, 1998). Trajetórias são, assim, segundo Bourdieu (1996, p. 292), uma "série de posições sucessivamente ocupadas por um mesmo agente ou por um mesmo grupo de agentes em espaços sucessivos".

Selecionei sindicalistas dirigentes do CPERS/SINDICATO (gestão 2014/2017) tendo em vista sua representatividade. Tal sindicato reúne trabalhadoras/es em educação de escolas públicas de ensino básico da rede do estado do Rio Grande do Sul, constituindo-se, conforme informações do seu site ${ }^{4}$, no "segundo maior sindicato da América Latina", representando mais de 80.000 trabalhadoras/es em educação. É um dos 52 sindicatos filiados à CNTE Confederação Nacional de Trabalhadores em Educação.

No momento das entrevistas, as mulheres contavam com 65 anos (duas delas), 62, 61, 56, 54, 47, 31 e 29 anos de idade. As entrevistas foram realizadas em 2016 e duraram, em média, 1h30min. A todas foi explicado o objetivo do estudo conforme os protocolos éticos vigentes para a pesquisa no país, de tal forma que todas assinaram um termo de consentimento para o uso de suas entrevistas. Ainda assim, a transcrição de suas entrevistas foi enviada a quem assim o quis. Por fim, síntese do estudo, sob forma de vídeo, foi encaminhada ao sindicato.

Na sequência, discorrerei sobre os principais resultados da análise feita.

\section{Breve exposição sobre o tema "gênero" na CNTE}

Para que se compreenda de forma mais ampla a análise presente neste texto, é preciso situar o ingresso e o desenvolvimento do debate sobre gênero na CNTE, responsável por elaborar políticas a serem encaminhadas por seus sindicatos de base.

Essa discussão tem presença dentro da CNTE aproximadamente da mesma forma e ritmo em que ocorre no âmbito da CUT, à qual está filiada [segundo Gindin (2015), desde 1988, quando ainda se chamava CPB - Confederação dos Professores do Brasil]. Assim, em 1993 a CNTE cria a Secretaria da Mulher Trabalhadora, transformada em Secretaria de Relações de Gênero apenas na primeira gestão da única mulher presidente da organização, Juçara Maria Dutra Vieira (2002/2005 e 2005/2008).

Com o passar do tempo o debate sobre gênero e diversidade sexual apresenta avanços na CNTE, especialmente por influência da Internacional da Educação, a qual está afiliada, sendo um dos reflexos desses avanços, no plano organizacional, a consecução da paridade na diretoria executiva a partir do Congresso de 2017. 
Neste processo existe uma participação cada vez maior de sindicalistas em eventos nacionais e internacionais sobre gênero - inclusive na Rede Internacional de Mulheres da Internacional da Educação da América Latina e na Marcha Mundial de Mulheres -, havendo o estímulo à formação de Coletivos de Mulheres e de LGBT+. Muitas campanhas e lutas têm sido desenvolvidas pela organização, no sentido de promover o empoderamento das mulheres, o alcance da equalização de gênero e o término da discriminação contra pessoas LGBT+.

Importância grande nesse movimento adquire a criação da Revista Mátria, publicada desde 2003 a cada dia 8 de Março e que, além de sistematizar a posição da organização sobre gênero, tem servido como ferramenta de formação e proposição de atividades concretas para o debate nas escolas. Assim, para ter-se uma ideia, na Mátria podemos encontrar proposições muito definidas de várias mulheres que têm feito parte das diretorias da Confederação, que não apenas apresentam propostas de lutas, mas o fazem com base num conceito preciso de gênero, perceptivelmente fruto de inúmeras discussões.

Mas a CNTE também tem se mantido atenta às questões relativas às políticas educacionais. No que tange às mudanças de enfoque em relação a gênero nos documentos nacionais, citadas na seção passada, a organização é contundente quanto ao seu equívoco:

A supressão dos temas associados às relações de gênero, à orientação sexual e a outras formas de preconceitos nos planos de educação impede que os estudantes tenham acesso aos conceitos e ao patrimônio histórico comum de lutas por igualdade de gênero e reconhecimento, proteção e promoção dos direitos humanos (...).

Gênero, enquanto categoria analítica, permite compreender e criticar desigualdades históricas entre homens e mulheres, assim como os preconceitos decorrentes da incapacidade de amplos setores sociais de entenderem a necessidade e o direito à livre transitividade de gênero para os travestis e transexuais" (CNTE, 2015, p. 187-188).

Não obstante, o fato de que sejam coerentes a análise e o enfrentamento de questões relativas a mulheres, LGBT+ e outras "minorias" dentro da organização a qual está fíliada a maioria dos sindicatos da educação pública no país não significa que todos os seus ativistas compartilhem das mesmas ideias e pautas de luta. Isso pode ser percebido de diversas maneiras, como na forma de organização interna de cada sindicato para atender à necessidade de contar com secretarias ou coletivos envolvidos com os temas citados; ou quanto à simples ampliação da representação de mulheres nas instâncias de direção. Santos (2020), para dar apenas um exemplo dos desafios que as organizações devem enfrentar, refere-se à diferença entre o reconhecimento das opressões evidenciadas e o reconhecimento formal dos sujeitos. Pode-se ter maior compreensão em relação à primeira modalidade de justiça social, mas estar-se distante ainda da segunda. Em suma, pode-se dizer que o avanço do tema gênero dentro das 52 entidades filiadas à CNTE é absolutamente desuniforme (Ferreira; Orsato; Coronel; Santos, 2018; Ferreira; Orsato; Santos; Coronel, 2018). 
Um elemento que colabora na determinação do compromisso das ativistas sujeitas dessa pesquisa com esses temas é o tipo de formação e de engajamento que tiveram com a política, o que, como veremos, em alguma medida acompanha a faixa etária. Para compreender isso, vamos começar com o curso de vida das sindicalistas.

\section{Trajetórias educacionais, profissionais e políticas das sujeitas da pesquisa}

Primeiramente assinalo que, para manter efetivamente o anonimato das informantes, pessoas reconhecidas no espaço sindical, não apresentarei seus perfis de modo sistemático e individualizado. Desta maneira, o que se pode dizer genericamente é que elas apresentam trajetórias educacionais, profissionais e militantes bastante ativas, sofridas e ricas em experiências; mas narradas como confissões, permitindo que fossem acompanhadas em seu processo pessoal de rememorar os caminhos da construção de sua autonomia. Como outras sindicalistas investigadas, elas não se veem como vítimas; ao contrário, são vencedoras num mundo difícil, pleno de lutas:

Eu me amo, porque eu, sabendo de onde eu vim, eu tenho profundo respeito por mim, e não é egocentrismo, não é falta de humildade, é reconhecimento de mim mesma, sabe? É reconhecimento de mim mesma, ninguém precisa saber por todas as experiências que eu passei, por todas as dificuldades, por todos os traumas que eu tive (Entrevistada G).

De forma genérica também pode-se assinalar que quase sempre fizeram seus estudos básicos em escolas públicas. Tendo genitores com pouco ou nenhum estudo, e muitas vezes irmãos na mesma situação, especialmente as professoras com mais idade foram as primeiras de suas famílias a conseguirem um grau acadêmico.

Antes de tornarem-se professoras algumas trabalhavam em diferentes ramos da economia (comércio, serviços, trabalho doméstico), participando de seus sindicatos. Nesse sentido, todas incluíram-se, quando crianças e jovens - e em suas palavras -, na "classe pobre", ou "muito pobre", com pais e mães trabalhadores manuais. Suas narrativas são plenas de informações sobre as dificuldades de sobrevivência e a luta pessoal para se profissionalizarem. Já na condição de docentes trabalharam em várias redes de ensino (além da estadual, em redes municipais ou na rede privada). Seu tempo de trabalho em escolas se situava, na altura das entrevistas, entre 21 e 31 anos para as mulheres mais velhas; as duas jovens tinham três anos de docência.

Nas escolas nas quais lecionaram ou lecionam, ademais da docência, muitas ocuparam cargos de direção ou coordenação. E elas denotam paixão por educar, rememorando as boas lembranças que têm disso. Em geral assinalam que a militância dá forma a seu trabalho pedagógico, à medida em que consideram que a atuação sindical se constitui numa experiência de formação diferente daquela obtida no ensino superior, o que as tornou mais criteriosas, responsáveis, comprometidas, tal como explicita uma informante: 
a nossa derrota não vai ser por salário, a nossa derrota vai ser quando a gente se desencantar com a educação, enquanto estiver viva ninguém derrota a escola pública, então o meu sonho, que eu persigo e acho que é comum de toda nossa direção, é fazer este resgate da escola pública, que eu tenho certeza que vale a pena, e eu me emociono cada vez que falo isso (Entrevistada A).

Em termos de participação política, suas experiências são igualmente ricas e ativas. Várias delas atuaram em movimentos sociais ou outros organismos de participação, tais como associação de bairro; sindicato de outro ramo; movimento de educação popular; movimento de mulheres; movimento estudantil; sendo que há, também, quem já tenha sido duas vezes candidata a vereadora ("para cumprir a cota das mulheres!"); quem foi candidata consciente de ter sido usada "para os homens se elegerem"; quem já foi cargo de confiança de uma deputada; e quem fez parte de direção partidária. As informantes mais jovens participaram do movimento estudantil, com mais ênfase no universitário, compondo direções de um DCE (Diretório Central de Estudantes).

Quanto ao sindicato estudado, suas participações destacam-se por seu grande envolvimento, desde seus núcleos (seções) sindicais, passando por diferentes tipos de representação estadual, até chegarem à direção central, excetuando as jovens, cujo percurso será comentado adiante. Na direção central há muitas informantes que já participaram de mais de uma gestão, e algumas compuseram/compunham também a direção da CUT estadual, de forma que as mulheres com mais idade cumpriram entre três e cinco mandatos sindicais. Frente à composição política da diretoria, pertencem a correntes sindicais diferentes, predominando a Articulação Sindical, sendo que também há indicações de pertencimento à CTB (Central dos Trabalhadores e Trabalhadoras do Brasil), à Articulação de Esquerda Sindical e à CSD (CUT Socialista e Democrática). O partido de filiação mais citado é o PT (Partido dos Trabalhadores), com seis filiadas. Há também filiadas ao PC do B (Partido Comunista do Brasil) e ao PDT (Partido Democrático Trabalhista). Apenas uma das informantes não é filiada a nenhum partido.

Com exceção das duas diretoras mais jovens, todas as outras são mães e, algumas, avós. Não é unânime que seus filhos e filhas tenham ensino superior, nem seus cônjuges. Das nove mulheres, três indicam ser separadas, e as demais vivem com cônjuges; também não parece haver endogamia quanto a casamentos com docentes.

Uma das informantes não é docente de escola, integrando o corpo administrativo escolar, sendo formada em Pedagogia. Curiosamente, no que se refere às oito sindicalistas docentes, com exceção de uma que atua no ensino técnico (e que fez o Esquema I para formação docente), todas as demais são formadas em História e/ou Geografia e em Letras. Apenas a mais jovem das professoras possui curso de mestrado, enquanto três cursaram especialização e uma estava cursando à altura das entrevistas (via EaD).

Mais interessante, ainda, para marcar o trajeto educacional de mulheres originárias de setores de classe baixos, é o fato de que, embora tenham estudado em escolas públicas, quase todas fizeram seu curso superior em faculdades isoladas ou universidades privadas, optando 
por cursos que existiam em suas cidades de origem, não necessariamente o que gostariam de ter feito, e após interrupções nos estudos; algumas durante a criação de seus filhos e/ou trabalhando e estudando. Aliás, a maioria dos casos narrados fizeram-me lembrar da proposição de Bourdieu (1999b) no que se refere à "causalidade do provável”, ou seja, suas opções, na verdade, são resultado do número restrito de oportunidades oferecidas a seu grupo social, conforme o capital social e o capital cultural de sua família de origem e segundo o estágio de cumprimento das tarefas sociais delegadas às mulheres.

Por fim, somente estudaram em instituições de ensino superior públicas, durante sua vivência numa das cidades mais importantes do estado, as mulheres mais jovens, cujos pais (pai e mãe), inclusive, também possuem curso superior.

Se vários desses aspectos parecem ser comuns entre as entrevistadas e outras professoras que foram informantes em projetos anteriores (Ferreira, 2006a; 2012), há algumas características que são específicas das agora entrevistadas, talvez pelo acúmulo de discussão existente nos sindicatos no período decorrido entre as primeiras pesquisas e a atual. Em primeiro lugar, não encontrei menções à ideia de docência como destino das mulheres. Elas chegaram à docência quase sempre por falta de alternativa e não transformaram essa questão objetiva em justificativa teleológica. Por exemplo, apenas duas do grupo (as com mais idade) mencionaram haver feito magistério em nível secundário, curso feito por um grande número de nossas entrevistadas anteriores; e quase ninguém enfatizou um desejo precoce de ser professora. Encontra-se, sim, uma associação, feita por algumas poucas, entre docência e maternidade, no sentido de que as mulheres, por serem mães, teriam uma sensibilidade especial para o trabalho pedagógico.

Em segundo lugar, é muito marcante o fato de que a maioria cursou o ensino superior em instituição privada, o que explicita, por um lado, quais alternativas de educação superior eram oferecidas às pessoas provenientes de classes populares e habitantes de cidades não metropolitanas. Isso nos dá uma ideia da oferta e tipo de instituições frequentadas pelo professorado do estado com faixa etária semelhante à das professoras investigadas. Observando-se a origem e o atual local de trabalho das entrevistadas, é perceptível que vêm de municípios situados em todos os rincões do estado, que apresentam variados tipos de ofertas educacionais. Aliás, esta composição faz parte da tentativa de maior extensão possível da atuação sindical, em termos geográficos, pois o CPERS/SINDICATO está organizado em 42 Núcleos sindicais, com área de abrangência semelhante a das Coordenadorias Regionais de Educação. Neste sentido, na composição de chapas para a Direção Central da organização sindical tenta-se trazer líderes de distintas partes do estado do Rio Grande do Sul.

O terceiro aspecto incisivo, e talvez a maior diferença que já encontrei com meus estudos anteriores, tem a ver com a mudança geracional introduzida com a presença das duas professoras jovens na direção sindical. Neste caso temos que pensar que as experiências de vida de um grupo e de outro não apenas são variadas, mas são, às vezes, díspares. As docentes mais jovens têm uma experiência educacional completamente diferente de suas colegas, aproveitando os avanços permitidos pela expansão do ensino superior público e por serem moradoras de um grande centro urbano à época de seus estudos. Têm uma vivência profissional curta. Têm uma experiência militante forjada em outro momento do país, pois 
nasceram pós-ditadura. Têm valores culturais e desejos diferentes com relação a seu futuro e ao papel da militância. Têm demandas feministas mais transparentes e objetivas.

De um ponto de vista estratégico a introdução de pessoas jovens nos grupos diretivos pretende atrair novas gerações à filiação sindical (Internacional da Educação, 2016). De fato, segundo a responsável pelo Departamento de Juventude, há apenas 5\% de filiados com até 35 anos no sindicato. E, em números de 2016, o CPERS/SINDICATO tinha $62 \%$ de filiados/as aposentados/as, o que deve indicar uma base consideravelmente maior e mais jovem que não está sindicalizada ${ }^{5}$. Perguntadas sobre sua introdução precoce na direção central de um importante sindicato, considerando seu curto tempo de nomeação para o funcionalismo público do estado do Rio Grande do Sul (aproximadamente um ano), uma das mulheres responde dessa maneira:

eu acho que a minha experiência anterior no movimento estudantil, também na política, no partido, foi a bagagem que eu trouxe para chegar tão rápido nesse espaço (...) É que na verdade a gente também tinha essa ideia de colocar jovens, da renovação, porque teve dois concursos no governo Tarso [Genro], em 2012 e 2013, o que renovou um pouco a categoria. Foram 14 mil nomeações, então nosso objetivo também era representar esse público novo que estava entrando (Entrevistada C).

A outra jovem tem explicação semelhante:

eu tive a nomeação, me filiei ao sindicato, foi bem junto, e aí automaticamente minha ação, minha organização política passa a ser na atividade sindical. Antes era nos movimentos de juventude, agora na atividade sindical (...).

Essa indicação veio de uma plenária estadual da minha corrente, teve uma plenária estadual e um dos temas era conjuntura e indicação de pessoas para composição de chapa tanto para os núcleos - porque o CPERS tem 42 núcleos -, quanto para a direção central. Daí teve uma avaliação coletiva que eu tinha uma relação ... eu era jovem, recém tinha entrado no magistério e era importante esta representação e, enfim, estava entrando, tinha um gás novo, renovação também da militância sindical, foi nesse bojo todo que eu acabei entrando (Entrevistada B).

Assim, a trajetória militante mais curta do que as demais sindicalistas é uma característica que diferencia sobremaneira as jovens das mais maduras. Ademais, a vivência familiar das informantes também parece apontar para uma discussão maior sobre questões educacionais e, inclusive, sobre ativismo social e político, de forma diferente das informantes anteriores: "era uma família que trazia esses debates para o meio familiar, a gente participava de movimentos, passeatas ... o debate sempre esteve muito presente, então a gente sabia que era uma coisa muito importante para a sociedade, essa coisa da educação" (Entrevistada C). 
Contudo, as informantes jovens expressam uma crítica ao ritmo e características do cotidiano sindical que as informantes mais maduras não expressam, seja porque essas últimas não queiram demonstrar possíveis fragilidades do sindicato a entrevistadores/as externos/as; seja porque, realmente, não tenham esse tipo de crítica; seja porque relevem os desconfortos como fazendo parte da atividade. É assim que uma das professoras jovens analisa a atividade sindical:

O tempo inteiro as vozes são para serem convencidas ou silenciadas, tu não consegues, a partir de uma troca de diferentes opiniões, construir um ponto comum de uma opinião e que aquilo seja crescente, sabe? E isso me faz entender que é menos educativo (...). E quando tu és nova, como eu, ainda é mais potencializado. Então eu acho que o sindicalismo é o exercício do convencimento de um ponto de vista (Entrevistada B).

Além disso, sua percepção sobre as questões que devem ser objeto de atenção sindical também é distinta. Assim, embora reconheça que o sindicato defende prioritariamente a educação pública, ela critica:

o sindicato faz pouquíssima reflexão de como é estar lá ou em que aspecto esta escola tem que se transformar para além do salário, para além da estrutura, para além de ter luz, internet... o que é esta escola lá dentro, como funciona, o sindicalismo fala quase nada sobre isto.

Eu tenho necessidade de falar mais sobre educação, mais de ação pedagógica, alguns chamam isso de politização da ação sindical. Acho que a gente fala muito de defasagem salarial, a gente fala muito de defasagem estrutural de escola, mas a gente tem dificuldade de dizer que educação a gente quer (Entrevistada B).

E ambas as entrevistadas jovens citam certa necessidade de retornar à escola e aos estudos em educação para qualificar seu trabalho e suas reflexões.

Examinar a trajetória das sindicalistas tem valor em si, ao iluminar e dar voz a pessoas cuja existência nem sempre é objeto dos estudos sobre sindicalismo (Lenarduzzi; Teixeira, 2017). Mas, além disso, pode colaborar para a nossa compreensão das diferentes representações de gênero que habitam um mesmo grupo, reunido por sua cumplicidade em cumprir um programa de ação sindical e por seu companheirismo construído no cotidiano, apesar das várias divergências originárias de suas concepções ideológicas e políticas. São algumas dessas representações que veremos a seguir.

\section{Importância e significado do gênero na escola, segundo mulheres sindicalistas em educação}

Como vimos anteriormente, a CNTE proporciona uma elaboração sobre o tema da diversidade de gênero e orientação sexual bastante desenvolvida e disseminada por meio de 
suas publicações, eventos e campanhas. Nos congressos da CNTE muitas correntes têm se dirigido a apresentar resoluções sobre gênero, para que a entidade prepare suas lutas, redirecione suas formas de estruturação interna e apresente orientações às entidades de base.

Da mesma forma cabe dizer, antes de tudo, que as mulheres entrevistadas não podem ser vistas como vítimas, muito ao contrário. São mulheres empoderadas, que trilharam duros caminhos para conquistar seu espaço na esfera pública, e aí chegaram.

Não obstante, entendendo o gênero na condição de habitus (Bourdieu, 1999a), não existe linearidade entre suas compreensões a respeito e as posições definidas em nível da CNTE. As entrevistadas percebem, em grande número, desigualdades de gênero, mas dão valor diferente a lutas sobre isso e a lutas relativas a condições de trabalho e salário dos e das profissionais da educação. Algumas expressam preconceito em relação a orientações sexuais não normatizadas, enquanto outras são claramente sexistas. Desta maneira, por exemplo, a criação de um Departamento de Gênero dentro do CPERS/SINDICATO não se deveu à convicção de todos os componentes da diretoria sobre sua importância, mas sim a partir da pressão de algumas correntes políticas para que isso acontecesse.

Como diz Paraíso (1998, p. 5), quando se discute gênero em muitas ocasiões as docentes não têm ferramentas para compreender a importância do tema; daí porque seus olhos "demonstram o constrangimento por não saber lidar com os temas lançados". De fato, as sindicalistas entrevistadas não necessariamente partilham uma concepção comum sobre gênero e/ou causas feministas que lhes habilite a compreender e posicionar-se sobre o processo de produção e reprodução de representações e de identidades sexuais e de gênero. Vou sublinhar aqui alguns aspectos captados nas entrevistas.

Primeiramente, vejamos sua compreensão sobre a interferência do gênero sobre as práticas pedagógicas. Algumas delas evitam discutir o tema, pois sua prioridade é defender as e os trabalhadores docentes. Assim, parecem ter receio em apresentar ideias que poderiam ser interpretadas como críticas ao professorado ou como perda de foco nas questões sindicais e na valorização de uma boa educação para todos (e todas): o professorado deve ser defendido, não criticado. Tal postura pode ser observada quando as entrevistas se dirigem à existência de diferenças nas práticas pedagógicas e nas interações segundo o gênero do professorado e do alunado. Enquanto existe uma vastíssima literatura a indicar diferenças de comportamento de professoras e professores ao tratarem alunos e alunas, ou ao elaborar as avaliações pedagógicas; diferentes formas de estudantes tratarem professoras e professores etc., para algumas entrevistadas isso não se destaca, não existe. Por outra parte, às vezes algumas delas parecem supor que queiramos atribuir maior competência às mulheres.

Vejamos alguns posicionamentos, para compreender os distintos argumentos. Revela a Entrevistada A, negando a possibilidade de diferença: “os relapsos são relapsos tanto os homens quanto as mulheres, os comprometidos são comprometidos tanto como homem quanto mulher, eu não vejo muita diferença neste sentido pelo sexo, mas sim pelo comprometimento com a educação". E nisso é seguida por uma colega, a Entrevistada E: "Eu acho que não. Professor bom é professor bom. Professor que tem conhecimento não interessa o sexo".

Outras, contudo, percebem diferenças, mas as explicam com conotação sexista: 
o homem é muito mais descansado que a mulher, a mulher trabalha muito mais. Claro que sempre tem suas exceções. Então o que eu notava no curso noturno é que o homem não se preocupava muito com a educação em si, ele se preocupava mais em ganhar o seu dinheiro, acho que isso já é uma coisa natural, a questão da sobrevivência, de manter família, e a mulher não, a mulher já vai para um lado familiar, já vê a questão psicológica, a questão do aluno (Entrevistada D).

Os professores homens eles são mais brincalhões, as mulheres são mais comedidas, elas procuram ver mais a responsabilidade, como elas já têm aquela [função] de mãe, elas procuram ver as responsabilidades dos seus alunos, então elas têm mais preocupação em relação à aprendizagem, né, a questão pedagógica (Entrevistada F).

Um dos problemas com esse tipo de avaliação é, por um lado, estar carregada de preconceitos; por outro - o principal deles, analiticamente falando -, é atribuir atitudes e comportamentos com base na natureza das pessoas conforme seu sexo, sem perceber que os comportamentos são resultado da cultura, não da genética.

Uma terceira posição - e é justo esclarecer que é de uma das jovens do grupo -, percebe o gênero como determinante dos processos educativos. Como aborda uma série de fenômenos presentes em análises acadêmicas, a citação da transcrição está mais longa que as demais:

Vai determinar, determina muito. Absolutamente determina. (...) Eu avalio que condiciona conteúdos, condiciona disposição de datas comemorativas, umas em detrimento de outras, eu acho que de fato somos [maioria, mais de 87\%] de mulheres na categoria e muitas vezes nós não estamos nos cargos diretivos da escola. Existe uma concepção de que uma escola bem administrada é uma escola administrada por homens, que existe uma maior e melhor condição de trabalho. Existe uma concepção, vou dizer bem a palavra que a gente ouve nas escolas, de que quando mulher está dirigindo tem muita picuinha, quando homem é diretor a escola é mais objetiva, é mais organizada, a burocracia funciona melhor. Então acho que existe muito forte ainda, e acho que temos pouco espaço de promoção para reflexão, acho que hoje não temos nenhuma promoção desse debate, eu não tenho memória da educação promover esse debate de forma séria, as escolas reproduzem muitos estereótipos, desde a estética, da vestimenta, a expectativa que a gente tem sobre as alunas e sobre os alunos, meninos e meninas, não é a mesma. Eu acho que a organização do ambiente escolar ainda reproduz isso, desde essa coisa assim: "ah, o banheiro dos homens, o banheiro das mulheres, o banheiro dos professores, o banheiro das professoras, o banheiro dos funcionários, o banheiro das funcionárias". E eu acho que atualmente a escola não é um espaço que questiona e subverte, acho que é um espaço que reproduz, tanto nos cargos, como a gente já falou, quanto no tratamento da temática. Ainda falar sobre gênero é falar lá no oito de março e colar várias imagens de mulheres bem-sucedidas, lindas, maravilhosas, fazer um cartaz de homenagem às mulheres 
da escola, quando na verdade a necessidade seria um trabalho bem mais profundo (Entrevistada B).

E, por fim, outra visão sobre o tema é oriunda de sindicalista que não encontra diferenças nas práticas pedagógicas, mas nas interações, indicando que alunos (e alunas) tendem a respeitar mais os professores, tendo as professoras mais dificuldade para serem reconhecidas e respeitadas, sejam essas jovens ou maduras: "se a professora for bonita, jovem, eles ficam tentando tirar para assediar (...); se a professora não for jovem, não for bonita, daí eles dizem: 'veio essa velha, museu'” (Entrevistada G). A fala, então, remete a práticas sexistas também existentes no corpo discente.

Tendo em mente, então, as interpretações das entrevistadas quanto às interações entre gênero e práticas cotidianas de escolarização, o próximo elemento a abordar trata da percepção das mesmas sobre o preparo do professorado para lidar com temas relativos a gênero e sexualidade em aula. Tornou-se perceptível que quanto menor o reconhecimento de diferenças de gênero, maior o distanciamento de uma problematização sobre a necessidade de a escola e o professorado enfrentarem o debate sobre gênero.

Uma mirada rápida em qualquer site de busca permite ver a abundância de estudos que têm se dedicado a examinar a questão da formação docente para atuar com os temas gênero e diversidade sexual, elementos bastante ausentes dos currículos de curso de licenciatura no país e muito limitados, também, em termos de políticas educacionais. Carvalho (2010) assinala que esse debate apenas começa em 1998, com os Parâmetros Curriculares Nacionais para o Ensino Fundamental (Tema Transversal Orientação Sexual) e com o Referencial Curricular Nacional para a Educação Infantil. Em termos de formação continuada de docentes, na primeira década do século foi proposta para todo o país a realização dos chamados GDEs, cursos de educação a distância Gênero e Diversidade na Escola, através de parceria da Secretaria Especial de Políticas para as Mulheres (SPM) com o Centro LatinoAmericano de Estudos de Sexualidade (Clam) (Silva; Rossato; Oliveira, 2013). Em análise de um destes cursos GDE, Carvalho se surpreende, ao final dos trabalhos, com a "persistência do sexismo, do androcentrismo, do heterossexismo, da misoginia e da homofobia, mesmo quando se é exposto/a à crítica dessas problemáticas" (Carvalho, 2010, p. 84). Em outro texto sobre esses cursos (Silva; Ferreira, 2019), mesmo encontrando resultados muito positivos no que tange às consequências dos cursos sobre a percepção e as atitudes pedagógicas das professoras, as autoras avaliaram que variam as iniciativas das docentes quanto a efetivar ações sobre gênero na escola:

identificamos ações que buscam romper com a cultura de preconceito e discriminação de gênero nas escolas, em que pese a existência de ações marcadas por um habitus de legitimação da naturalização das desigualdades de gênero (Silva; Ferreira, 2019, p. 15).

Além disso, a introdução dos temas nos currículos escolares e acadêmicos demonstra uma insuficiência que tende a se aprofundar agora, momento de incursões conservadoras. 
Como já indicado, o simples uso do termo "gênero" tem sido vetado em muitíssimos estados e municípios brasileiros ao elaborarem seus planos de educação, atitude corroborada até pelo Conselho Nacional de Educação ao aprovar, em 16 de dezembro de 2017, a Base Nacional Comum Curricular para a educação infantil e o ensino fundamental, sem nenhuma menção a gênero e orientação sexual.

Por esse raciocínio, se se retiram as informações, a formação e o espaço para debate, para combater esse vazio apenas o oposto é logicamente sensato: é preciso promover campanhas sobre a necessidade de cursos para habilitar docentes, ao trazer uma discussão que tende a ser não visibilizada. Santos e Ferreira (2015), sobre pesquisa realizada com 208 docentes de unidades escolares de educação básica na cidade de Pelotas (RS), sublinham que a percepção do professorado quanto à sua competência para abordar gênero e sexualidades em classe e sobre a responsabilidade da escola quanto a isso foi maior entre docentes que participaram de algum curso de formação continuada. Silva e Ferreira também sinalizam que "a importância de uma política de formação mais perene foi uma das indicações de muitas professoras como fundamental para o fortalecimento do trabalho sobre gênero nas escolas (Silva; Ferreira, 2019, p. 13).

Neste sentido, o que dizem nossas informantes? É unânime a ideia de que o professorado não está preparado, modificando-se levemente os motivos alegados para a falta de preparo. A formação ocupa a atenção de todas, mas algumas mencionam a falta de formação inicial; outras matizam dizendo que essa formação inicial até ocorreria em instituições federais, mas não nas instituições privadas, visto as informações que têm a respeito; enquanto outras indicam a falta de formação continuada.

Não obstante, há quem perceba a parcela de conservadorismo que atinge a sociedade, os governos, pais e mães e o professorado como responsável pela falta de interesse de muitos na formação e pela ausência de trabalhos em sala de aula com o alunado (que, aliás, algumas mencionam fazer em suas classes).

Para compreender melhor essa questão e captar as possíveis discussões que talvez ocorram dentro da direção sindical, precisaríamos novamente retomar o corte geracional para entender a diferença de posicionamentos, sem reduzir essa diferença apenas à questão etária, e, sim, a vertentes de natureza cultural (incluindo a moral) e política, mas reconhecendo que esse matiz existe. De tal modo, uma das professoras mais jovens resume os motivos da falta de preparo:

Porque falta formação continuada; porque os docentes ainda são guiados $e$ orientados religiosamente por suas crenças pessoais e não administram isto porquanto são educadores públicos e o Estado tem que ser laico; e porque nós vivemos numa sociedade intensamente preconceituosa (Entrevistada B).

Enquanto outra professora, da geração mais antiga, argumenta incluindo-se na categoria docente e defendendo-se: 
Nós não somos preparados para isso, pra dar isso, nem os psicólogos são, como é que nós professores que estamos ali quatro anos vamos lidar com a diversidade nas escolas? Tem que abordar, mas como uma coisa natural. Os pais têm que ter papel mais importante nisso aí, acho que está falhando muito é a família (Entrevistada D).

Entretanto, para elucidar a necessidade de levar em conta diferenças de caráter cultural e/ou político, e não apenas as diferenças etárias, basta citar a fala de outra professora com mais idade, que defende a necessidade de enfrentamento das questões de gênero na escola, esclarecendo que ainda que não esteja "condenando os professores", está "chamando à responsabilidade que temos de abrir esse debate" (Entrevistada A).

Sobre isso gostaria de explicar a permanência entre docentes de atitudes preconceituosas ou receosas do tratamento do gênero e da diversidade sexual na escola, sustentando-me novamente em Carvalho (2010), com sua análise bourdieusiana, para quem o gênero é um conceito "de difícil sensocomunização". Ela assinala a força da resistência pela necessidade psicossomática que as pessoas têm de agarrar-se a identidades fixas, enquanto a crítica feminista questiona exatamente essa fixidez. Essa situação revela a eficácia do habitus e se torna mais aguda pela articulação entre gênero e orientação sexual, no plano da heteronormatividade. Além disso, o debate de gênero contesta a formação religiosa e moral das pessoas, que usualmente tende a ser conservadora e valorizadora do patriarcado e da heteronormatividade.

Por fim, as representações já descritas das mulheres sujeitas desta pesquisa, com todas suas variações, podem nos ajudar a compreender um último elemento a desenvolver aqui: o que faz o CPERS/SINDICATO ser dirigido por mulheres há tanto tempo - desde 1996 uma mulher ocupa a presidência do sindicato -, diferenciando-se da maioria dos sindicatos ligados à CNTE?

Primeiramente, é unânime entre as entrevistadas que o CPERS/SINDICATO é hegemonizado por mulheres, pois isso ocorre há mais de duas décadas e já está moldado nas memórias das/os ativistas em geral. A resposta imediata de várias delas à questão: "quais os fatores que têm permitido um número maior de mulheres a ocupar cargos de liderança por várias gestões seguidas no CPERS?" em princípio é um pouco tautológica, mas quando a conversação se aprofunda as respostas vão, aos poucos, tornando-se mais complexas.

A tendência de várias é afirmar a naturalidade da situação, frente à feminização da docência: se há mais mulheres no ofício, é natural que sejam dirigentes sindicais. Mas, logo, têm que ampliar a explicação quando lembramos que essa não é a norma nacional, pois os homens são presidentes numa proporção muitíssimo maior do que sua presença nas bases da categoria (Ferreira; Orsato; Coronel; Santos, 2018). Como solicitamos, na sequência, comentários sobre o tipo de cultura a circular no sindicato - se feminina ou masculina -, se estabelecem respostas diferenciadas conforme, novamente, as concepções de gênero apresentadas. Vejamos alguns exemplos, que começam pela questão numérica e se estendem para a criação de uma cultura feminina: 
Em que outro espaço as mulheres militariam que não no CPERS? Essas mulheres que militavam no CPERS, elas foram bem rebeldes desde o passado e acho que até hoje, né, até hoje 6 . Não é fácil aceitar uma mulher militante, um homem aceitar uma mulher militante, não é fácil para ele (Entrevistada $\mathrm{C}$ ).

Porque a mulher é que manda no magistério estadual [risos], porque tu vais olhar quantos homens e quantas mulheres, nós somos a maioria. Somos a maioria ... não tem como. (...) talvez da nossa formação, da gente ser formador de opinião, onde tem esse culto em busca de liberdade... e aí somos também a maioria de associados, a maioria do magistério é mulher, a gente se sente mais forte aqui, não saberia te dizer outra coisa (Entrevistada E).

Primeiro, porque nós somos maioria aqui no estado, não poderia ser homem, do meu ponto de vista não poderia ser homem, porque já tivemos grandes lideranças [do sexo masculino] e agora ultimamente têm sido mulheres (...). Segundo, o segundo acho que não, acho que não vou dizer que as mulheres são mais capacitadas [risos] (Entrevistada D).

Paulatinamente as reflexões vão se encaminhando para a construção de quadros militantes e a afirmação de uma cultura feminina capaz de neutralizar a superioridade geométrica masculina. Assim, uma sindicalista atribui semelhanças com o fato de que o estado possui, historicamente, mulheres militantes; mas pondera que houve a construção da ideia de que as mulheres poderiam liderar o CPERS, posto que em outras partes do país e do mundo os homens são maioria nos sindicatos em educação:

A gente é um pouco Anita Garibaldi sabe, a gente peleia lado a lado com os homens e às vezes se eles se bobeiam a gente pula por cima [risos]. (...) A Zilah Totta foi o nome talvez mais simbólico, porque a Zilah assume depois do Hermes [sic; entre os dois houve a gestão de Glacy Corrêa], que tinha feito uma luta fantástica, e ela entra ainda no período de ditadura e ela tem enfrentamentos, tem fotos dela com fuzil na cara e ela era um toquinho de gente, assim magrinha, mas ela demonstrou muita força. Então isso foi criando uma ideia no nosso sindicato, até por ser a maioria, aonde quem está no sindicato desde o início lá tenta reafirmar o papel da mulher (Entrevistada A).

A constituição de uma cultura feminina dá-se, então, para algumas, pela presença majoritária de mulheres, com uma forma diferente de militar e pela construção de quadros femininos. Algumas concluem que o CPERS já não teria mais uma cultura masculina porque isso foi descontruído - o que significaria, por outra parte, que em outro momento teria imperado uma cultura masculina... Essas questões estão esboçadas em certas afirmativas: "como nós, mulheres, somos mais pedagógicas e didáticas, leva mais a serem mulheres à frente do sindicato" (Entrevistada F). 
Eu acho que a mulher, ela tem mais sensibilidade de perceber as falhas, e também está mais, digamos assim, aberta para receber, para ouvir, pra, pra, pra juntos construir, digamos, a saída. Os homens muitas vezes se acham autossuficientes (Entrevistada $\mathrm{H})$.

A Entrevistada B dá uma série de exemplos, afirmando que o fato de haver mulheres expoentes faz com que pensar no sindicato conduza à lembrança delas, sendo o contrário também válido, pois frente à categoria feminina é impossível não haver a geração de lideranças mulheres. E continua:

Acho que o fato de ter tido esta frequência de mulheres na liderança é porque elas são filhas de uma geração que lutou fortemente pela redemocratização, pela luta das mulheres na política, (...) é uma geração marcada por estes símbolos, tanto que a maioria delas tem 60 anos, 65 anos (...). É ao mesmo tempo a geração das mulheres que saíram pra trabalhar e da geração das mulheres que se separaram, que não entenderam nos seus casamentos o fim social da sua vida, entendeu? Elas foram subversivas de alguma forma, elas são de uma geração que contestou o casamento, que contestou a criação do filho só pra ela, então isso ... mulheres que buscaram sua autonomia.

Interessantemente, embora reconheça o protagonismo das mulheres no CPERS, essa é a única sujeita (como vimos, mais jovem) que faz uma leitura não essencialista ou não linear do fenômeno analisado, dizendo que o sindicato é majoritariamente de mulheres, mas não é um sindicato feminista:

"A cultura do sindicato, do CPERS/SINDICATO é masculina! A cultura do CPERS/SINDICATO é masculina! As pessoas disputam fala, e elas disputam divergência num formato masculino: é no grito, é batendo na mesa, é roubando urna, é nãnãnã... é tudo aquilo que o patriarcado faz há mil anos" (Entrevistada B).

Ora, talvez por essa multiplicidade de perspectivas sobre comportamentos e identidades femininas e masculinas também haja tanta divergência nas respostas à questão: "um maior número de mulheres líderes sindicais implica numa maior atenção aos problemas sociais das mulheres?" As respostas são tão dispersas que vale a pena reproduzi-las todas. A Entrevistada E responde que "sim, com certeza", e ao ser questionada sobre o motivo, afirma que "todas as lutas que eu tive na minha vida, desde pequena, eu tenho como referência sempre uma mulher lutadora, uma mulher vencedora".

"Sim", também, é a resposta da Entrevistada H, para quem "com certeza" há uma maior atenção aos problemas das mulheres, pois "eu acho que a mulher com certeza tem uma visão mais global, e também esse olhar para as necessidades das mulheres". A mesma ideia é apresentada pela Entrevistada G, pois "até pelo próprio fato de ser mulher, a gente faz uma leitura, a gente se conecta com as mulheres, (...) atenta para os problemas das nossas companheiras de uma forma que a gente sente na pele". 
A Entrevistada I tem uma posição um pouco diferenciada das anteriores, pois acredita que a atenção ocorre "quando as mulheres assumem que têm que debater estas questões sociais, que tem mulher que até não assume que tem que debater, acha que está tudo normal". Mas, em seguida, pondera que "sim", tendo em vista o trabalho da gestão vigente no CPERS/SINDICATO, que criou o Departamento de Gênero.

Dentre as respostas negativas à questão, também há variabilidade. A Entrevistada D acredita que "não" porque este não é o foco do sindicato, que deve estar voltado às questões educacionais. A Entrevistada F responde que "acho que não", após uma pausa para reflexão. Frente à insistência da entrevistadora, destaca que realmente existe maior sensibilidade feminina, embora os colegas homens da direção também sejam "uns queridos".

As últimas três sindicalistas têm visões mais semelhantes em sua conclusão da falta de atenção às questões sociais das mulheres. A Entrevistada $\mathrm{C}$ diz que não, embora o grupo atual comece a estimular uma sensibilidade. "Inclusive, por exemplo, se a mulher [sindicalista] está sofrendo violência em casa ela não traz para o sindicato, ela não traz porque ela sabe que isso vai ser ruim para ela... como se isso fosse fragilizá-la diante das pessoas".

A Entrevistada A reflete sobre o caráter periférico da questão independentemente do sexo do dirigente sindical:

Acho que não, por isso a nossa preocupação de pôr isto na pauta, não só [a questão] da mulher, mas a questão da homofobia que é muito forte, mas há isso; e tem uma característica que daí é igual homem e mulher que é aquilo que eu te disse das lideranças, do apossamento da base, eu quero ser a líder, eu comando com mão de ferro, e daí tanto os homens como as mulheres são iguais, é interessante (...) até pra nós, mulheres militantes isso não se torna centro, é sempre periférico, e mesmo com isso que nós estamos fazendo [criação do Departamento] continua sendo periférico".

E, nessa linha de reflexão, a Entrevistada B resume o estado do problema: "Não implica porquê ... não é porque existe uma maioria de mulheres, ou muitas mulheres, que a consciência sobre a temática seja natural. É preciso ter consciência da importância dos temas e da opressão que a gente sofre pra ... isso ser um tema gerador presente".

Em síntese, encontramos três tipos de percepções: a ideia de que não é objeto do sindicato preocupar-se com as questões sociais das mulheres; a identificação imediata entre ser mulher e atentar para essas questões; e a perspectiva de que isso não é automático, com variações no motivo: porque há algumas mulheres que pensam que tais problemas são do âmbito privado; porque é periférico dentro das reivindicações sindicais; e por entender que essa problematização ocorre quando há consciência, não sendo esse o caso ainda.

$\mathrm{O}$ conjunto de questões ou elementos do debate sobre gênero aqui trazidos revelam o quanto esse campo ainda necessita de maior discussão e visibilidade, bem como faz-se importante o conhecimento das diferentes teorias que o embasam. Essa discussão qualificada mal começa a ingressar nos sindicatos da área educacional, se tomarmos por referência estudos a respeito (Santos, 2020). De fato, embora as histórias de vida das entrevistadas sejam 
carregadas de exemplos sobre como o gênero lhes constituiu, poucas delas têm uma percepção mais forte desse processo.

\section{Considerações finais}

Estudiosas da memória feminina explanam que as mulheres associam mais facilmente suas lembranças aos episódios familiares, aos lugares sociais que ocupam no âmbito privado (Perrot, 1989; Catani et al., 1997). Ao recorrer a estudos sobre o tema, Piscitelli assim os resume:

a memória feminina estabelece referências temporais associadas ao ciclo familiar, diferenciando-se da masculina, que é datada com precisão [...] as lembranças das mulheres preservam temas integrados num domínio no qual o afetivo e o individual são fundamentais, em tanto as dos homens guardam relatos de uma história não necessariamente oficial, mas sim de uma história coletiva, de uma história espetáculo (Piscitelli, 1993, p. 160).

Posso relatar, também, o marcante envolvimento das informantes com suas narrativas, o que permitiu contar parcela do fenômeno estudado desde uma perspectiva não usual. Como diz Perrot, a memória, "forma de relação com o tempo e com o espaço, (...) como a existência da qual ela é o prolongamento, é profundamente sexuada" (1989, p. 18). E assim transcorreram por nossos olhos muitas histórias tocantes, com viés de gênero, embutidas em relatos do cotidiano, que revelam as dificuldades de ser mulher em ambientes que não foram criados de forma inclusiva. Para quem, como nossas entrevistadas, o "sindicato é como uma cachaça", "é um vírus"; para quem "a militância conduz toda a minha vida"; as mulheres contam com certa tristeza como o exercício da militância afetou sua vida familiar. Algumas tiveram maridos inconformados; outras temeram pelo cuidado de seus filhos; há quem mencione que felizmente as novas gerações de mulheres militantes não tiveram que passar pela trajetória de sacrifícios que as mais antigas passaram. E, desta forma, as entrelinhas também permitiram não apenas dar voz a quem não é ouvida pela epistemologia dominante, mas conhecer outras facetas dos processos de desigualdade social.

Lenarduzzi e Teixeira apreenderam o mesmo, em estudo sobre mulheres sindicalistas docentes argentinas:

as vozes das mulheres sindicalistas entrevistadas expressam modos de relatar pouco propensos a uma narração heroica e épica. Ou antes: trata-se de mulheres que pensam e sentem, projetam e improvisam, acertam e erram, lutam e fechamse em si mesmas (Lenarduzzi; Teixeira 2017, p. 399).

No lugar de valorizar-se como militantes merecedoras de ocuparem lugares nas direções sindicais, no lugar de apontar a carreira como um desafio galgado de forma intrépida, elas contam com pormenores o seu processo de atração ao sindicato e sobre os convites que 
receberam para fazer parte da direção, explicitando sua insegurança na ocasião e assinalando dificuldades para tomada de decisão ("pensei várias vezes se deveria ou não vir" Entrevistada F; "vou atender ao chamado, a gente não tem que ir onde gosta, mas onde é necessário" - Entrevistada I).

Não obstante, ao refletirmos sobre a convocação dessas mulheres à militância, pode-se concluir que o espaço sindical lhes permitiu o empoderamento. Tendo em vista as categorias de Lenarduzzi (2017) para localizar o tipo de desafios e as características das representações de sindicalistas mulheres (superação de provas existenciais, aquisição de autonomia, influência geracional e falta de reflexão sobre a condição de gênero), pode-se dizer que a convocação à militância foi respondida, pelas mulheres do CPERS/SINDICATO, de forma incisiva, aceitando as provas existenciais pelas quais tiveram de passar, no caminho de sua autonomia. Não obstante, nem todas localizam com clareza que tipo de dificuldades corresponde à sua condição de gênero, tendo peso, nesse processo, o pertencimento geracional.

Gostaria de enfatizar esse aspecto. Como vimos, com a intenção de conhecer o grupo mais propenso a desenvolver o gênero como objeto de lutas e discussão, um dos objetivos era apreciar as trajetórias das sindicalistas do CPERS/SINDICATO na gestão analisada. A ideia subjacente era a de que o exame das trajetórias permitiria perceber a influência do gênero em suas histórias de vida, o que poderia nos dar pistas, também, por analogia, sobre os caminhos educacionais e profissionais de professoras pertencentes aos mesmos grupos geracionais, ao menos nesta região do país. As vivências das entrevistadas manifestaram-se ricas em experiências, semelhantes em vários aspectos, nas quais a militância adquire importância ímpar e que são certamente caracterizadas pelo gênero, embora nem todas tenham consciência disso. É perceptível, no entanto, ser a diferença geracional um dos traços marcantes a definir posicionamentos diversos sobre vários aspectos da vida das professoras, tanto no que se refere às concepções sobre gênero, quanto à vivência sindical e profissional.

Especificamente quanto às representações de gênero, percebem-se, ao menos duas concepções, cada qual determinando o valor que dão ao debate a respeito. Uma primeira abordagem localiza as desigualdades de gênero como vigentes em todos os espaços sociais, associando-se a preconceitos contra demais minorias e ao machismo propriamente dito. Por outra parte, a outra abordagem identifica diferenças entre homens e mulheres, mas com certo viés sexista em favor das mulheres. Nem todas as mulheres, contudo, acreditam que seja tarefa do sindicato debater gênero com seus filiados e filiadas. Mesmo algumas daquelas que são a favor apresentam dificuldades para definir caminhos para a atuação sindical nesse campo, delegando essa tarefa exclusivamente ao Departamento de Gênero e Diversidade. Da mesma forma, muitas não têm certeza ou são contrárias ao tratamento do tema gênero dentro da escola. Além disso é possível, novamente, indicar diferenças de concepção conforme a idade das informantes, pois tornou-se claro que as informantes jovens têm mais familiaridade com o tema e menos desconforto na hora de discuti-lo.

De fato, por ser o gênero um construto cultural, por envolver, por uma parte valores, por outra, disposições inculcadas em nossos corpos e mentes, encontramos uma multiplicidade de representações a respeito, mesmo quando as pessoas pertencem, como acontece no caso 
deste estudo, a uma mesma diretoria de sindicato de trabalhadores em educação. É possível dizer que várias das temáticas abordadas pela CNTE, a qual o CPERS/SINDICATO está filiado, não fazem parte das preocupações de algumas das mulheres, especialmente pertencentes à geração mais antiga.

Logo, a consciência sobre as desigualdades advindas das relações de gênero é pouco vislumbrada, ao menos no âmbito da consideração sobre a necessidade de lutar contra essas desigualdades também no espaço sindical, construindo caminhos mais incisivos em direção a relações mais horizontais. Esse é um caminho difícil; daí porque dizer-se, retomando a bela conclusão da Entrevistada G: "já que essa luta é longa, que ela comece logo".

\section{Notas}

1. Texto produzido com financiamento do CNPq, sob forma de auxílio à pesquisa (Chamada MCTI/CNPq/MEC/CAPES $n^{\circ}$ 22/2014) e bolsa de produtividade em pesquisa (PQ-2014). Agradeço a colaboração, na coleta de dados, de Andréia Orsato, Luciano Pereira dos Santos e Márcia Cristiane Völz Klumb Coronel, componentes de meu grupo de pesquisas; e às entrevistadas, por sua generosidade em expor suas memórias e posicionamentos.

2. Em números mais recentes, "de 2014 a agosto de 2019 foram apresentados 226 projetos de leis nos legislativos municipais e estaduais de todo o país inspirados nas ideias do movimento Escola sem Partido e de movimentos ultraconservadores similares" (https://www.cnte.org.br/index.php/menu/comunicacao/posts/noticias/73170-em-novadecisao-stf-afirma-que-e-dever-do-estado-abordar-genero-e-sexualidade-na-escola). Eles têm dado origem a várias Arguições de Descumprimento de Preceito Fundamental, julgadas pelo STF, que tem declarado a inconstitucionalidade de leis que excluem das políticas educacionais referências a questões de gênero.

3. Cabe assinalar, ainda, que essa problemática continua vigente, tendo se tornado mais evidente sobretudo desde o golpe que destituiu a Presidenta Dilma Rousseff e, mais tarde, com a eleição de Jair Bolsonaro para a presidência da república.

4. https://cpers.com.br/organograma/. Acesso em: 01 abr. 2020.

5. A Secretaria Estadual de Educação divulgou, para 2016, o número de 47.955 docentes em exercício na rede estadual (cf: http://servicos.educacao.rs.gov.br/pse/srv/estatisticas.jsp?ACAO=acao1.) Para o mesmo ano o CPERS nos indicou haver 28.837 sócios na ativa.

6. Especificamente em relação a essa fala, devo chamar a atenção sobre o acerto do questionamento: de fato, no que se refere a mulheres com acesso à educação escolarizada, historicamente a docência tornou-se um espaço para sua expressão política e social, tendo sido professoras, também, várias participantes em movimentos feministas em muitos países do mundo.

\section{Referências}

ALMEIDA, Jane Soares de. Mulher e educação; a paixão pelo possível. São Paulo: UNESP, 1998.

ALONSO, Graciela; MORGADE, Graciela. Educación, sexualidades, géneros; tradiciones teóricas y experiencias en un campo en construcción. IN: MORGADE, Graciela; ALONSO, Graciela (comps.). Cuerpos y sexualidades en la escuela; de la 'normalidad' a la disidencia. Buenos Aires: Paidós, 2008. p. 1939.

AUAD, Daniela. Educar meninas e meninos: relações de gênero na escola. São Paulo: Contexto, 2006.

BORN, Cláudia. Gênero, trajetória de vida e biografia: desafios metodológicos e resultados empíricos. Sociologias, Porto Alegre, ano 3, n. 5, p. 240-265, jan./jun. 2001. Disponível em: https://seer.ufrgs.br/sociologias/article/view/5736/3326. Acesso em: 5 abr. 2020.

BOURDIEU, Pierre. A dominação masculina. Rio de Janeiro: Bertrand Brasil, 1999a. 
BOURDIEU, Pierre. A ilusão biográfica. In: FERREIRA, Marieta de Moraes; AMADO, Janaína (orgs.). Usos \& abusos da história oral. 2. ed. Rio de Janeiro: Fundação Getúlio Vargas, 1998. p. 183-191.

BOURDIEU, Pierre. As regras da arte: gênese e estrutura do campo literário. São Paulo: Cia das Letras, 1996.

BOURDIEU, Pierre. Futuro de classe e causalidade do provável. In: NOGUEIRA, Maria Alice; CATANI, Afrânio (org.). Pierre Bourdieu: escritos de educação. 2. ed. Petrópolis: Vozes, 1999b. p. 81-126.

BRANDÃO, Zaia. Entre questionários e entrevistas. In: NOGUEIRA, Maria Alice; ROMANELLI, Geraldo; ZAGO, Nadir (orgs.). Família \& Escola; trajetórias de escolarização em camadas médias e populares. 2. ed. Petrópolis: Vozes, 2003. p. 171-183.

BRUSCHINI, Cristina; AMADO, Tina. Estudos sobre mulher e educação: algumas questões sobre o magistério. Cadernos de Pesquisa, São Paulo, n. 64, p. 4-13, fev. 1988.

CAPPELLIN, Paola. Viver o sindicalismo no feminino. Estudos Feministas, Rio de Janeiro, número especial, p. 271-290, 1994.

CARRIERI, Alexandre de P.; TEIXEIRA, Juliana Cristina; NASCIMENTO, Marco César R. (orgs.). Gênero e trabalho: perspectivas, possibilidades e desafios no campo dos estudos organizacionais. Salvador: EDUFBA, 2016.

CARVALHO, Maria Eulina P. de. Gênero é um conceito complexo e de difícil sensocomunização. Considerações a partir de uma experiência de formação docente. Instrumento - Revista de Estudo e Pesquisa em Educação, Juiz de Fora, v. 12, n. 2, jul./dez. 2010, p. 75-87. Disponível em: https://periodicos.ufjf.br/index.php/revistainstrumento/article/view/18685. Acesso em: 05 jun. 2020.

CARVALHO, Marília P. de. Mau aluno, boa aluna? Como as professoras avaliam meninos e meninas. Estudos Feministas, Florianópolis, v. 9, n. 2, 2001, p. 554-574. Disponível em: http://www.scielo.br/pdf/ref/v9n2/8640.pdf. Acesso em: 05 jun. 2020.

CARVALHO, Marília P. de. No coração da sala de aula; gênero e trabalho docente nas séries iniciais. São Paulo: Xamã/FAPESP, 1999.

CATANI, Denice, BUENO, Belmira; SOUSA, Cynthia; SOUZA, Maria Cecília. História, memória e autobiografia na pesquisa educacional e na formação. In: ___ (orgs.). Docência, memória e gênero: estudos sobre formação. São Paulo: Escrituras Editora, 1997. p. 13-48.

CONFEDERAÇÃO NACIONAL DE TRABALHADORES EM EDUCAÇÃO. Gênero e diversidade sexual na escola; a CNTE apoia os movimentos sociais. Retratos da Escola, Brasília, v. 9, n. 16, p. 187-194, jan./jun. 2015. Disponível em: http://retratosdaescola.emnuvens.com.br/rde/article/view/493/606. Acesso em: 10 jun. 2020.

CORONEL, Márcia Cristiane V. K. Gênero e sindicalismo docente: uma análise da produção acadêmica na pós-graduação. 2014. 120f. Dissertação (Mestrado em Educação) - Faculdade de Educação, Universidade Federal de Pelotas, Pelotas, 2014.

DELGADO, Maria Berenice. Mulheres na CUT: um novo olhar sobre o sindicalismo. In: BORBA, Ângela; FARIA, Nalu; GODINHO, Tatau (orgs.). Mulher e política; gênero e feminismo no Partido dos Trabalhadores. São Paulo: Fundação Perseu Abramo, 1998. p. 209-224.

FERREIRA, Márcia O. V. Notas sobre as relações entre identidade e sindicalismo docentes. Educação \& Sociedade, Campinas, v. 28, n. 99, p. 377-399, maio/ago. 2007. Disponível em: http://www.scielo.br/pdf/es/v28n99/a05v2899.pdf. Acesso em: 09 jun. 2020.

FERREIRA, Márcia O. V. "Siempre el destino acaba llevándonos hacia donde tenemos que estar": trayectorias escolares y profesionales de profesoras y profesores militantes. In: FELDFEBER, Myriam; OLIVEIRA, Dalila (comps.). Políticas educativas y trabajo docente; nuevas regulaciones ¿nuevos sujetos? Buenos Aires: Novedades Educativas, 2006a. p. 143-160.

FERREIRA, Márcia O. V. Sindicalismo docente, mulheres e representações de gênero; delineamento final. Pelotas: FaE-UFPel/CNPq, 2018. 121p. Relatório de Pesquisa. 
FERREIRA, Márcia O. V. Sobre trajetórias e identidades docentes: sindicalistas como sujeitos de pesquisa. In: PIZZI, Laura C. V. et alii. Trabalho docente: tensões e perspectivas. Maceió: EDUFAL, 2012. p. 133-150.

FERREIRA, Márcia O. V. Somos todos trabalhadores em Educação? Reflexões sobre identidades docentes desde a perspectiva de sindicalistas. Educação e Pesquisa, São Paulo, v. 32, n. 2, p. 225-240, maio/ago. 2006b. Disponível em: http://www.scielo.br/pdf/ep/v32n2/a02v32n2.pdf. Acesso em: 09 jun. 2020.

FERREIRA, Márcia O. V.; ORSATO, Andréia; CORONEL, Márcia C. V. K; SANTOS, Luciano P. Gênero e representação política: um estudo sobre a representação sindical de trabalhadoras/es em educação. InterAção, Goiânia, v. 43, n. 3, p. 681-696, set./dez. 2018. Disponível em: http://dx.doi.org/10.5216/ia.v43i3.46058. Acesso em: 09 jun. 2020.

FERREIRA, Márcia O. V.; ORSATO, Andréia; SANTOS, Luciano P. dos; CORONEL, Márcia C. V. K. Abordagem das desigualdades de gênero e diversidade sexual em sindicatos de trabalhadoras/es em educação: o caso da CNTE. Revista Brasileira de Estudos Pedagógicos, Brasília, n. 252, p. 404-428, maio/ago. 2018. Disponível em: http://dx.doi.org/10.24109/2176-6681.rbep.99i252.3398. Acesso em 11 jun. 2020.

FERREIRA, Márcia O. V.; SANTOS, Luciano Pereira dos; CORONEL, Marcia. C. V. K.; ORSATO, Andréia. Políticas sindicais para gênero e diversidade sexual; entrevista com Juçara Maria Dutra Vieira. Cadernos de Educação, Pelotas, n. 57, p. 3-26, jul./dez. 2017. Disponível em: https://periodicos.ufpel.edu.br/ojs2/index.php/caduc/article/view/12805/8036. Acesso em: 09 jun. 2020.

FRASER, Nancy. From Redistribution to Recognition? Dilemmas of Justice in a 'Post-Socialist' Age. New Left review, v. 1, n. 212, p. 68-93, july/aug. 1995.

GINDIN, Julián. Por nós mesmos; o sindicalismo docente de base na Argentina, no Brasil e no México. Rio de Janeiro: Azougue, 2015.

HALL, Stuart. The work of representation. In: Signifying Practices. London: Sage, 1997. p. 13-74.

INSTITUTO NACIONAL DE ESTUDOS E PESQUISAS EDUCACIONAIS ANÍSIO TEIXEIRA. Sinopse Estatística da Educação Básica 2019. Brasília: Inep, 2020. Disponível em: http://portal.inep.gov.br/sinopses-estatísticas-da-educação-básica. Acesso em: 01 maio 2020.

INTERNACIONAL DE LA EDUCACIÓN. Plan de Acción para la Igualdad de Género 2015 - 2019. 2016. Disponível em: http://download.ei-ie.org/Docs/WebDepot/EI_GEAP_2015_SPA_web.pdf. Acesso em: 10 jun. 2020.

IÑIGUEZ, Lupicinio. Prática da análise do discurso. In: ciências sociais. Petrópolis: Vozes, 2004. p. 105-160.

(coord.). Manual de análise do discurso em

KERGOAT, Danièle. Divisão sexual do trabalho e relações sociais de sexo. In: HIRATA, Helena et alii (orgs.). Dicionário crítico do feminismo. São Paulo: UNESP, 2009. p. 67-75.

LENARDUZZI, Zulma V. Generaciones de profesoras sindicalistas argentinas: fragmentos de historia (19842016). 2017. 268f. Tese (Doutorado em Educação) - Faculdade de Educação, Universidade Federal de Minas Gerais, Belo Horizonte, 2017.

; TEIXEIRA, Inês. Experiencias de mujeres sindicalistas docentes en Argentina: una mirada desde las relaciones de género. In: BAUER, Carlos et alii (orgs.). Sindicalismo e associativismo dos trabalhadores em educação no Brasil - com escritos sobre a Argentina, Colômbia, Inglaterra, Japão e Peru. v. 3. Jundiaí: Paco Editorial, 2017. p. 397-404.

LOURO, Guacira L. Gênero, sexualidade e educação; uma perspectiva pós-estruturalista. 2. ed. Petrópolis: Vozes/CNTE, 1998.

LOURO, Guacira L. Prendas e anti-prendas. Porto Alegre: Ed. da UFRGS, 1987.

MIGUEL, Luís F.; BIROLI, Flávia. Introdução: teoria política feminista, hoje. In: Teoria política feminista; textos centrais. Vinhedo: Horizonte/UFF, 2013. p. 7-54. (orgs.). 
PARAÍSO, Marlucy A. Currículo e identidades: a produção de gênero, sexualidade e etnia na formação da professora. In: REUNIÃO ANUAL DA ASSOCIAÇÃO NACIONAL DE PÓS-GRADUAÇÃ̃O E PESQUISA EM EDUCAÇÃO - ANPEd, 21., 1998, Caxambu. Anais (disquete).

PARAÍSO, Marlucy A. Currículo e relações de gênero: entre o que se ensina e o que se pode aprender. Revista Linhas, Florianópolis, v. 17, n. 33, p. 206-237, jan./abr. 2016. Disponível em: http://www.revistas.udesc.br/ index.php/linhas/article/view/1984723817332016206/pdf_102. Acesso em: 05 jun. 2020.

PERROT, Michelle. Práticas da história feminina. Revista Brasileira de História, São Paulo, v. 9, n. 18, p. 918, ago./set. 1989.

PISCITELLI, Adriana. Tradição oral, memória e gênero: um comentário metodológico. Cadernos Pagu, Campinas, n. 1, p. 149-171, 1993.

RAMOS, Marlise N. Escola sem Partido: a criminalização do trabalho pedagógico. In: FRIGOTTO, Gaudêncio (org.). Escola "sem" partido: esfinge que ameaça a educação e a sociedade brasileira. Rio de Janeiro: UERJ/LPP, 2017. p. 75-85.

RODRÍGUEZ, Eduardo. Igualdad de género y movimiento sindical. In: ABRAMO, Laís (ed.). Trabajo decente y equidad de género en América Latina. Santiago: Oficina Internacional del Trabajo, 2006. p. 289-324.

ROSEMBERG, Fúlvia. Educação sexual na escola. Cadernos de Pesquisa, São Paulo, n. 53, p. 11-19, maio 1985.

SANTOS, Luciano P. dos. Políticas LGBT+ em sindicatos de trabalhadoras/es em educação. 2020. 228f. Tese (Doutorado em Educação) - Faculdade de Educação, Universidade Federal de Pelotas, Pelotas, 2020.

SANTOS, Luciano P. dos; FERREIRA, Márcia O.V. Interferência da formação continuada para o posicionamento de docentes brasileiros sobre sexualidades e gênero. Revista IRICE, Rosario, v. 29, n. 29, p. 11-43, 2015. Disponível em: http://www.irice-conicet.gov.ar:8080/portal/pda/9a969dbf-e2ee-47048340-d18213d3eebb/tool/22306f5f-abf1-432a-aeab-3879e245a8cc. Acesso em: 09 jun. 2020.

SCHIEBINGER, Londa. O feminismo mudou a ciência? Bauru: EDUSC, 2001.

SILVA, Cristina B. da; ROSSATO, Luciana; OLIVEIRA, Nucia A. S. de. A formação docente em história; igualdade de gênero e diversidade. Retratos da Escola, Brasília, v. 7, n. 13, p. 453-465, jul./dez. 2013. Disponível em: http://retratosdaescola.emnuvens.com.br/rde/article/view/318/488. Acesso em: 05 jun. 2020.

SILVA, Erineusa M. da; FERREIRA, Eliza B. Os movimentos das professoras da educação básica na constituição das políticas de gênero na escola. Educação e Pesquisa, São Paulo, v. 45, e200235, 2019. Disponível em: https://www.scielo.br/pdf/ep/v45/1517-9702-ep-45-e200235.pdf. Acesso em: 16 set. 2020. Epub Sep 16, 2019. https://doi.org/10.1590/s1678-4634201945200235.

SILVA, Ivanderson P. da. Em busca de significados para a expressão "ideologia de gênero". Educação em Revista, Belo Horizonte, v. 34, e190810, 2018. Disponível em: http://www.scielo.br/pdf/edur/v34/19826621-edur-34-e190810.pdf. Acesso em 29 abr. 2020.

VIANNA, Claudia. A produção acadêmica sobre organização docente: ação coletiva e relações de gênero. Educação \& Sociedade, Campinas, ano XXII, n. 77, p. 100-130, dez. 2001. Disponível em: http://www.scielo.br/pdf/es/v22n77/7047.pdf. Acesso em: 05 jun. 2020.

VIANNA, Claudia et alii. Gênero, sexualidade e educação formal no Brasil: uma análise preliminar da produção acadêmica entre 1990 e 2006. Educação \& Sociedade, Campinas, v. 32, n. 115, p. 525-545, abr./jun. 2011. Disponível em: http://www.scielo.br/pdf/es/v32n115/v32n115a16.pdf. Acesso em: 28 abr. 2020.

WILLIAMS, Christine L. The Glass Escalator: Hidden Advantages for Men in the "Female" Professions. Social Problems, v. 39, n. 3, p 253-267, aug./1992. 


\section{Correspondência}

Márcia Ondina Vieira Ferreira: É mestre em Educação (UFRGS) e doutora em Sociologia (Universidad de Salamanca, Espanha), com pós-doutorado na FLACSO/Argentina. Bolsista de Produtividade em Pesquisa (CNPq), coordena o Grupo de Pesquisas Processo de Trabalho Docente e está vinculada ao PPGE/UFPel.

E-mail: marciaondina@uol.com.br

Texto publicado em Currículo sem Fronteiras com autorização da autora 